ORNL/M- -1245

DE91 000536

Monthly Progress Report

\title{
Building Thermal Envelope Systems and Materials (BTESM) and Research Utilization/Technology Transfer Progress Report for DOE Office of Buildings Energy Research
}

JuTy 1990

\author{
Compiled by Gabrielle Burn \\ for \\ Jeffrey E. Christian, Program Manager \\ Energy Division
}

\footnotetext{
Prepared by the

Oak Ridge National Laboratory Oak Ridge, Tennessee 37831 operated by

Martin Marietta Energy Systems, Inc. for

U.S. DEPARTMENT OF ENERGY under contract DE-AC05-840R21400
} 


\section{CONTENTS}

I. BUILDING THERMAL ENVELOPE SYSTEMS AND MATERIALS (BTESM) Page

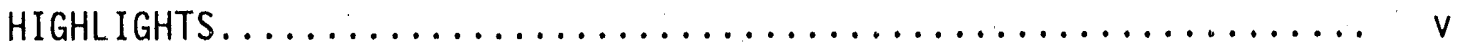
ABSTRACT .................................. vii

A. IMPLEMENTATION

1. Administration/Technical Support/Selected Projects...... 1

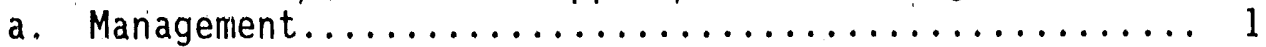

b. Reports Published This Period.................. 2

c. Conferences and Meetings of Interest............ 3

d. Consultants Report....................... 4

B. BUILDING MATERIALS PROGRAM

\section{Task B1. Advanced Materials Research}

1. Alternative Materials for CFC-Based Foam Insulations..... 6

2. Thermal Resistance Measurements and Data Base of CFC-Replacement Thermal Properties for Foam Insulation Products....................... 8

3. Investigation of the Substitution of Environmentally Acceptable Blowing Agents in Foam Insulation: Means to Achieve Equivalent or Approved Energy Efficiency........9

Task B2. Performance of Currently-Used Materials

1. Mode1s, Methods, Measurements................... 10

2. Thermal Insulation Studies...................... 12

3. Standard Reference Material Development............... 12

4. Residential Insulation Corrosiveness................ 13

5. Residential Insulation Corrosiveness/Consultant's

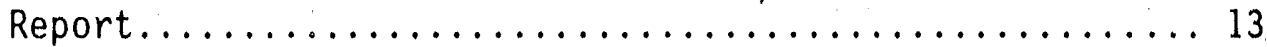

6. Research and Development Data to Define the Thermal Performance of Reflective Materials Used to Conserve

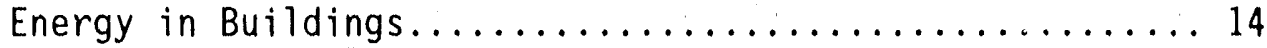

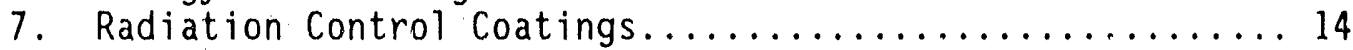

Task B3. Building Materials Program Management Support

1. Support Activity.......................... 15

C. BUILDING ENVELOPE SYSTEMS

WALL PERFORMANCE

1. Thermal Mass Simplified Design Tool Assessment.......... 18

2. Dynamic Evaluation of Thermal Bridges................ 19

3. Validation of Moisture-Transfer Model................ 20 
C. BUILDING ENVELOPE SYSTEMS (cont'd)

\section{ADVANCED WALL SYSTEMS}

1. Moisture Control Handbook........................ 21

\section{FOUNDATION SYSTEMS}

1. Building Foundations Research Agenda............... 22

2. S1 ab Foundation Benchmark Mode1........................... 22

3. Foundation Thermal Performance Simplified

Prediction Tool............................... 23

\section{ROOF SYSTEMS}

1. Roofing Research Center........................... 24

2. Large Scale Climate Simulator................................. 24

3. IEA Annex on Low Slope Roof Systems.......................... 25

4. Attic Testing on the LSCS............................ 25

5. Field Testing of Isocyanurate Foams with Aiternate Blowing Agents................................. 26

6. Roof Mechanical Properties Research Apparatus.............. 27

7. Roofing Industry Committee on Wind Issues............... 27

BUILDING DIAGNOSTICS

1. Solar Reflectance Measurements in the Field...........28

D. COOPERATIVE PROJECTS

1. Cooperative Industry/Government Research Project

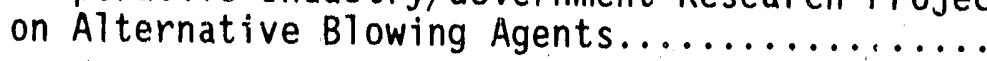




\title{
HIGHLIGHT
}

\section{SECOND SYMPOSIUM ON INSULATION MATERIALS-- TESTING AND APPLICATIONS}

\author{
October 10-12, 1991 \\ Gatlinburg, Tennessee \\ SPONSORED BY ASTM COMMITTEE C16 \\ $\mathrm{ON}$

\section{THERMAL INSULATION} \\ Call for Papers: \\ Abstracts Due: \\ Abstract Acceptance Notification: \\ Manuscripts Due: \\ STP Available: \\ April 1, 1990 \\ August 1, 1990 \\ September 1, 1990 \\ January 1, 1991 \\ October 10, 1991
}

For more information, please contact Symposium Co-Chairmen:

Ron S. Graves

Oak Ridge National Laboratory

Post Office Box 2008

Building 4508

Oak Ridge, TN 37831-6092

615/574-5978

FAX 615/574-7721
Don C. Wysocki

Mobay Corporation

Penn Lincoln Parkway West

Pittsburgh, PA 15205

412/777-2574

FAX $412 / 777-2758$ 
Building Thermal Envelope Systems and Materials (BTESM) and Research Utilization/Technology Transfer Progress Report for DOE Office of Buildings Energy Research

\section{ABSTRACT}

The Monthly Report of the Building Thermal Envelope Systems and Materials (BTESM) Program is a monthly update of both in-house ORNL projects and subcontract activities in the research areas of building materials, wall systems, foundations, roofs, building diagnostics, and research utilization and technology transfer. Presentations are not stand-alone paragraphs every month. Their principal values are the short-time lapse between accomplishment and reporting and their evolution over a period of several months. 


\section{BUILDING THERMAL ENVELOPE SYSTEMS AND MATERIALS (BTESM)}

\section{A. IMPLEMENTATION}

\section{Administration/Technical Support/Selected Projects}

This task includes overall management for the BTESM Program with the emphasis on assuring that individual R\&D projects are performed via the best available expertise whether it be at universities, private iabs, professional associations, or national labs (including ORNL). Also included are: implementation of major conferences, workshops and seminars, assurance of BTESM staff participation in committee work (BTECC, NIBS, ASTM, ASHRAE, etc.), BTESM National Program planning jointly with the total building community, technical support to DOE, and oversight of selected technical projects not delegated to other tasks.

\section{a. Management (Jeffrey E. Christian/Pat M. Love, ORNL)}

Response to the April flyer requesting comments about the monthly report are still coming in. This month, the distribution list has been revised to include those who have expressed an interest in remaining on the list. Those who have not responded will be left on the list for one more month. The october publication will have a totally revised list.

The BTESM Program welcomes a new secretary: Kay Brock. Kay will be assisting Clara Brown, the program secretary.

Participated in the 1990 DOE On-Site Review poster session. This provided an opportunity to talk one-on-one about several BTESM research activities with Clyde Hopkins, President of Martin Marietta Energy Systems, Inc.; Murray Rosenthal, Deputy Laboratory Director; B. R. Appleton, Associate Director of Physical Sciences and Advanced Materials; David Reichle, Associate Director of Environmental Sciences and Biology; and Bill Fulkerson, Associate Director, Advanced Energy Systems. This exposure led to an invitation to provide a technical briefing to Alvin Trivelpiece, ORNL Director, and his Executive Committee on August 8, 1990, on Attic Thermal Performance Testing in the Large Scale Climate Simulator. A second spin-off resulting from the On-Site Review activity is that information was requested on the Roof Research Center National User Facility work with private industry for testimony to be given to Congress by Alvin Trivelpiece. The focus of this invited testimony will be to illustrate the potential within the National Laboratories to do much more work with private industry.

\section{EVENTS}

JuTy 10

Jeff Christian participated in a poster session for the DOE On-Site Review.

JuTy 19

H. A. Fine, University of Kentucky, at ORNL 
b. REPORTS PUBLISHED THIS PERIOD

None. 


\section{c. CONFERENCES AND MEETINGS OF INTEREST*}

$\underline{1990}$

September 3-6: International Symposium on Energy, Moisture, Climate in Buildings, sponsored by CIB International Council of Building Research, to be held in Rotterdam, The Netherlands.

September 26-28: ICAA 12th Annual Convention/Expo, sponsored by the Insulation Contractors Association of America, to be held at the Walt Disney World Swan Hotel in Orlando, Florida. For more information, contact R. Hartley Edes, ICAA, 15819 Crabbs Branch Way, Rockville, MD 20855, or cal1 (301) 590-0030.

September 30-0ctober 3: 33rd Annual Polyurethane Conference, sponsored by The Society of the Plastics Industry, Inc., to be held at Marriotts Orlando World Center Resort and Convention Center in Orlando, Florida. For more information, contact SPI, 355 Lexingtion Avenue, New York, NY 10017, or cal1 (212) 351-5425, TELEX: 12029, FAX (212) 697-0409.

October 14-17: ASTM C 16 Fall Meeting, Omni Royal, New Orleans, Louisiana.

October 23-26: Leaking Underground Storage Workshop, co-sponsored by the Environmental Sciences and Technology Division of the Georgia Tech Research Institute and the United States Environmental Protection Agency. The workshop will be held on the Georgia Tech campus in the Space Science Building. For more information, contact the training programs office at (404) 894-3806.

October 25-26: ASTM Symposium on Water In Exterior Building Walls: Problems and Solutions, to be held in Dearborn, Michigan. More information is available from Symposium Chairman Thomas A. Schwartz, Simpson Gumpertz \& Heger, Inc., 297 Broadway, Arlington, MA 02174, (617) $643-2000$.

December 10-12: Third Brazilian Thermal Science Meeting, ENCIT-90, to be held in Itapema, SC, Brazi1. For more information, contact Professor Alvaro T. Prata, Department of Mechanical Engineering, Federal University of Santa Catarina, P.0. Box 476, 88049 - Florianopol is-SC, Brazil, or call (0482) 335166, FAX (0482) 331519, or Telex 481317 FUEG $B R$.

1991

January 19-23: ASHRAE 1990 Winter Meeting, to be held in New York, NY. For more information, contact Judy Marshall or Jan Young, ASHRAE Meetings, 1791 Tullie Circle, NE, Atlanta, GA 30329, or call (404) 636-8400.

*Please send notices to Gabrielle Burn. 
April 17-19: Third International Symposium on Roofing Technology, sponsored by the National Institute of Standards and Technology; U.S, National Roofing Contractors Association; Canadian Roofing Contractors Association; National Research Council of Canada; International Waterproofing Association; CIB, and RILEM. The symposium will be held at the Montreal Convention Centre, Montrea1, Quebec, Canada. For more information, contact Walter Rossiter, NIST, Center for Building Technology, Building 226, Room B-348, Gaithersburg, MD 20899, or cal1 (301) 9/5-6719, FAX (301) 975-4032, TELEX TRT 197674 NIST WT.

October 10-12: Second Symposium on Insulation Materials--Testing and Applications, sponsored by ASTM Committee C 16 , to be held in Gatlinturg, TN. For more information, contact Symposium Co-Chairmen:

Ron S. Graves, Oak Ridge National Laboratory, P.0. Box 2008, Bldg. 4508, Oak Ridge, TN 37831-6092, (615) 574-5978; or Don C. Wysocki, Mobay

Corporation, Penn Lincoln Parkway West, Pittsburgh, PA 15205, (412) $777-2574$.

\title{
d. CONSULTANTS
}

\section{ACEC RESEARCH AND MANAGEMENT FOUNDATION}

Jack R. Warner

President

Washington, D.C. 20005

Subcontract ORNL/SUb-SE077/3

Deliver by: 05-31-90

A new contract is pending.

\section{BTECC WORKSHOPS AND FEASIBILITY STUDY BUILDING THERMAL ENVELOPE COORDINATING COUNCIL NATIONAL INSTITUTE OF BUILDING SCIENCES}

\author{
Bruce E. Vogelsinger \\ National Institute of Building Sciences \\ Washington, D.C. 20005 \\ Subcoritract ORNL/Sub-SC111/6 \\ De1iver by: $12-31-90$
}

No report. 
TASK B, BUILDING MATERIALS PROGRAM

The Building Materials Program includes work done at ORNL and work done by others on DOE-funded projects. The following pages include project reports for three areas:

\section{B1. ADVANCED MATERIALS RESEARCH}

Cooperative Government/Industry Project on Alternatives for CFC-Based Foam Insulation

High-Resistance Powder-Filled Evacuated Panels

B2. PERFORMANCE OF CURRENTLY-USED MATERIALS

Determination of properties of materials

Improvement of test procedures

\section{B3. MATERIALS PROGRAM MANAGEMENT SUPPORT}

Technology transfer

Coordination of subcontracted research 
BUILDING

MATERIALS

PROGRAM

TASK B1. ADVANCED MATERIALS RESEARCH

\title{
1. ALTERNATIVE MATERIALS FOR CFC-BASED FOAM INSULATIONS
}

\author{
D. L. McElroy, R. S. Graves, T. G. Kollie, and D. W. Yarbrough \\ Oak Ridge National Laboratory \\ Oak Ridge, Tennessee 37831-6092
}

This task is currently focused on two topics:

(1.1) The Cooperative Government/Industry Research Project for CFC Alternatives, and

(1.2) High-Resistance Powder-fllled Evacuated Panels (PEPS)

1.1 Cooperative Project. We corrected and returned the proofs for the manuscript, "Acceleration of Thermal Resistance Aging Using Thin Boards," for inclusion in the Proceedings of the 33rd Annual Polyurethanes Conference, Orlando, October 1-4, 1990. We responded to comments by ORNL reviewers of the manuscript, "Thermal Properties of Polyisocyanurate Foam Board Insulation Blown with CFC-11 Substitutes," which is to be presented at the Third International Symposium on Roofing Technology, Montreal, April 17-19, 1991. A paper entitled, "Thermal Resistance of Prototypical Cellular Roof Insulations, "was accepted by SPI Canada for the Second Workshop on Long-Term Thermal Performance of Cellular Plastics, Niagara, June 5-7, 1991. The paper is due March 15, 1991. We provided the Steering Committee Chairman with the current ASTM C 16.30 ballot on the scope of a new standard practice on long-term thermal resistance of gas-filled plastic foams.

The testing of thin-specimens provided thermal conductivity $(k)$ data on specimens aged for up to 290 days at $75^{\circ} \mathrm{F}$ and 190 days at $150^{\circ} \mathrm{F}$. New fits by a least squares method were made for the correlation with (diffusion coefficient $x$ time) ${ }^{1 / 2} /$ thickness to yield effective diffusion coefficients for air components into the foam and blowing agent out of the foam. These were used to obtain activation energies $(\Delta H)$ for these processes. The $\Delta H(a t r)$ values for the five foams had an average value of $7300 \mathrm{cal} / \mathrm{mole}$ and the $\Delta H$ (blowing agent) values differed for each foam but were in the range 3600 to $6800 \mathrm{cal} / \mathrm{mole}$. We obtained the MIT computer program for aging and are running cases for comparison to the thin specimen testing results. An alternative analysis that is similar to the Dow diffusion model was suggested and we plan to explore this model. The interlaboratory comparison of $k$ measurements at $75^{\circ} \mathrm{F}$ on two planed boards foamed with CFC-11 (age about 400 days) 
using 24 in. $x 24$ in. R-Matic apparatuses was completed in July. We are preparing a letter report for review by the participants. We completed a set of transient tests on these boards prior to initiating this comparison (see Section B?).

1.2 Pane1s. The ORNL Advanced R-Matic Apparatus was used to measure the thermal resistance ( $R$ ) of twn compact vacuum insulation (CVI) panels provided by the Solar Energy Research Institute. Each CVI panel was sandwiched near the midplane of a fiberglass batt, (R/in. $\left.4 \mathrm{hr} \cdot \mathrm{ft}^{2} \cdot{ }^{\circ} \mathrm{F} / \mathrm{Btu} \cdot \mathrm{in}.\right)$, nominally $24 \mathrm{in}$. by $24 \mathrm{in}$. by 4 in., and the composite $R$ was measured at $75^{\circ} \mathrm{F}$. A HEATING-7 heat transfer code was used to mode 1 the apparatus and to correct for the extraneous heat flows that resulted from the inhomogeneous and anisotropic properties of the CVI-fiberglass composite. The $R^{\prime} s$ for the two panels averaged over the surface were 2.30 and 2.84 $\mathrm{hr} \cdot \mathrm{ft}^{2},{ }^{\circ} \mathrm{F} / \mathrm{Bt} \mathrm{u}$ for panels $\mathrm{M}$ and $\mathrm{S} 1$, respectively. Without the thermal short-circuit provided by the CVIs stainless steel cladding, the $\mathrm{R}^{\prime} \mathrm{s}$ would have been 5.9 and $4.1 \mathrm{hr} \cdot \mathrm{ft}^{2} \cdot{ }^{\circ} \mathrm{F} / \mathrm{Btu}$, respectively. HEATING-7 models show that these higher short.circuit-free values are approached asymptotically as the size of the panel is increased, but require panel sizes in excess of $20 \mathrm{ft}$ by $20 \mathrm{ft}$ to be within $10 \%$ of these values. The effective $R$ of two panels separated by a thermal resistance of $R=0.6 \mathrm{hr} \cdot \mathrm{ft}^{2} \cdot{ }^{\circ} \mathrm{F} / \mathrm{Btu}$ was modeled, yielding a value of $2.65 \mathrm{hr} \cdot \mathrm{ft}^{2}{ }^{\circ} \mathrm{F} / \mathrm{Bt}$, $\mathrm{f}$ for the $\mathrm{M}$ pane1, which is a further reduction of about $7 \%$ due to the thermal short-circuit established between the two stacked panels. Models of the heat transfer mechanisms within the panel reveal that for the short-circuit-free case of pane $\mathrm{M}, 70 \%$ of the heat is transferred by conduction through the glass spheres and $30 \%$ by thermal radiation between the stainless steel cladding, if the total hemispherical emittance of the stainless steel was assumed to be 0.1 and the thermal conductivity of the glass spheres was 0.9 Btu. in. $/ \mathrm{hr}^{\mathrm{ft}} \mathrm{ft}^{2}{ }^{\circ} \mathrm{F}$.

We have developed a hand-held device to measure the internal pressure of a panel. Farly evaluations of the $1 \mathrm{ab}$-bench model have shown that the device can measure the pressure beneath a barrier film stretched over a cavity of known pressure with the resolution of the mercury manometer used as the standard $( \pm 1 \mathrm{~mm}$ of mercury). The internal pressures of panels measured with the device will be compared with those measured by the established method, which requires placing the panel in a vacuum chamber. Not only is the hand-held device an order of magnitude less expensive than the established method, but it also is much more amenable to use in automated panel fabrication assembly lines. 


\title{
2. THERMAL RESISTANCE MEASUREMENTS AND DATA BASE OF CFC-REPLACEMENT THERMAL PROPERTIES FOR FOAM INSULATION PRODUCTS
}

\author{
R. Zarr \\ National Institute of Standards and Technology \\ Gaithersburg, Maryland 20899
}

ORNL/IA-21513/24

Progress Report for June 1990:

Task A, Milestone 5 (Measure Materials on GHP and HFM): Six specimens of polyisocyanurate foam insulation were cut from three of the seven boards received in May. Specimens are faced with permeable organic/inorganic facers and are about 37.5 millimeters thick. Two specimens were measured using the following apparatuses: the NIST one-meter gliarded hot plate, the 610 millimeter heat-flow-meter (HFM) apparatus, and the 305 millimeter HFM. The thickness of each specimen was about 37.5 and 75 millimeters, respectively. Measurements of apparent thermal conductivity were conducted at a mean specimen temperature of 24 degrees Celsius, with a temperature difference of 22 degrees Celsius across the specimen. Prior to measurement, the two heat-fiow-meter apparatuses were calibrated using specimens of fibrous-glass board conditioned at 90 degrees Celsius and having a density of 138 kilograms per cubic meter.

Miscellaneous:

1. In order to improve the response time of the NIST one-meter guarded hot plate and the control of the inner guard, a member of the Heat Transfer Group has modeled the apparatus using the program TKSolver. Results indicate that an incremental PI (Proportional, Integral) control algorithm described by Stoecker \& Stoecker in Microcomputer Control of Thermal and Mechanical Systems provide faster and superior response than an algorithm based on classical position control theory. This is, in part, due to the replacement of the summation-error term el iminating integrator wind-up. Work is now in process to upgrade the software used to control the one-meter apparatus to incorporate the incremental PI control algorithm.

2. Four specimens of unbonded glass-fiber loose-fill insulation were prepared with assistance of the National Association of Home Builders (NAHB). Specimens will be measured as part of the 1990 ASTM C 687 Round Robin.

Task B, Milestone 3 (Measure New Foam Products): In accordance with the new direction proposed at the joint meeting of SPI/PIMA/NRCA/EPA/DOE on May 9, 1990, NIST will participate in series of small round robins with Oak Ridge National Laboratory and Jim Walter Research Corporation. For the first phase of the round-robin, ORNL will select polyisocyanurate foam boards blown with refrigerant-11 and circulate them to the two laboratories. Measurements will be conducted on the same type of heatflow-meter apparatuses at each laboratory. 


\title{
3. INVESTIGATION OF THE SUBSTITUTION OF ENVIRONMENTALLY ACCEPTABLE BLOWING AGENTS IN FOAM INSULATION: MEANS TO ACHIEVE EQUIVALENT OR APPROVED ENERGY EFFICIENCY
}

\author{
Glicksman, Burke, Lanciani, Mozgowiec, Page \\ Massachusetts Institute of Technology \\ rambridge, Massachusetts 02139 \\ ORNL/SUB-09099/14
}

\begin{abstract}
It has been difficult achieving a perfectly sealed evacuated packet using thin glass as the barrier material. Thus, to prove the theoretical R-values expected for such packets, flawed packets will be sealed in a flexible barrier material and tested for thermal performance. This will yield an indication of the performance of the powder/glass barrier packets if a perfect seal were accomplished.

Quantitative tests of various silica and ceramic samples mixed with $\mathrm{KBr}$ are under way using the pellet technique on the Fourier Tranform Infrared Spectrometer. Pycnometer tests of samples are in process. Combined results of these tests will give relationship between mass of sample and percent transmission of radiant energy. Testing dates are being established with Hosakawa Corporation for free use of the Mechanofusion AM-15 lab unit to fuse carbon and aluminum coatings to polymeric particles.
\end{abstract}

Testing the permeability of $N_{2}$ in one ORNL foam sample is in progress. The permeability analyzer, on loan from Holometrix, Inc., has been tested for possible thermal gradients within the test chamber. The measurements, with a precision of $+0.25^{\circ} \mathrm{C}$, indicated no gradient. The Holometrix, Inc., apparatus is designed for computer control. The Holometrix, Inc., apparatus is designed for computer control. A computer has been acquired to replace the temporary machine used until now. A paper summarizing blowing agent diffusion coefficients test results, to be presented at the 33rd Annual Polurethanes Conference in October, has been sent to the publisher. Uncertainty analysis of the constant volurne sorption permeability test is being reviewed. 
TASK B2. PERFORHANCE OF CURRENTLY-USED MATERIALS

\section{MODELS, METHODS, MEASUREMENTS - ORNL}

This task is currently focused on three topics:

1. Development and use of analytical models for heat transfer.

2. Development and use of flat insulation testers: the Unguarded Thin Heater Apparatus (UTHA) and the Advanced R-Matic Apparatus.

3. Measurement of the behavior of loose-fill attic insulation.

\subsection{Models-ORNL}

The MIT computer program has been obtained and can be used on the ORNL DEC 10 system. The MIT model has been used to calculate $\ell n$ as a function of $\sqrt{t} / \ell$ for long time periods to show the asymptotic value $(t \rightarrow \infty)$ of the thermal resistance. The model has been used to calculate on $(100 \mathrm{k})$ for a single diffusing species such as oxygen. The resulting curve can be analyzed using the method of least squares to compare input diffusion coefficients and diffusion coefficients calculated from $d e n(100 k) /(\sqrt{t} / \ell)$. Analys is of early time $(t<105$ days) calculated thermal conductivity showed that the diffusion coefficient for $0_{2}$ could be predicted from $d$ ln $(100 \mathrm{k}) / \mathrm{d} \sqrt{\mathrm{t}} / \mathrm{l}$ to within $12 \%$. The model has been used to show the effect of varying either the air-component diffusion coefficients or the blowing agent diffusion coefficient on the thermal resistance of the foam as a function of time up to 300 years.

\subsection{Methods-ORNI.}

The Unguarded Thin-Heater Apparatus (UTHA) and the Advanced RMatic were used to test boards for the cooperative project (see B.1.) We completed the first draft of an ORNL/TM report entitled, "The Unguarded Thin-Heater Transient-Test Method (Thermophysical Properties of Building Materials), " and the text is being typed. This report is due in August as an FY 1990 deliverable and contains the detailed background for a paper for the ASTM C 16 symposium.

The ORNL Advanced R-Matic Apparatus was used to test five insulation specimens prepared by Lawrence Berkeley Laboratory. A letter report was prepared that described and analyzed the results. This included a set of calculations using the HEATING-7 heat transfer code to model the test configuration of the LBL insulation picture-framed in polystyrene. The intent 
was to show what the $10 \mathrm{in.}$ by $10 \mathrm{in}$. heat flux transducer(HFT) senses in the picture frame technique. The HEATING-7 results showed that the HFT senses only one dimensional heat flow, i.e., it does not sense the perimeter polystyrene insulation. We are preparing a letter report for Auklen Insulation Company on R-value measurements on three blow-in blanket specimens.

\subsection{Loose-Fill Attic Insulation-ORNL}

In July, we completed thermal tests on Insul-Safe III for the 1990 ASTM C 687 Interlaboratory Comparison on the Thermal. Resistance of Loose-Fill Insulations. Insul-Safe III was tested in three $3 \mathrm{ft}$ by $4 \mathrm{ft}$ test frames in the UTHA and in three $2 \mathrm{ft}$ by $2 \mathrm{ft}$ test frames in the Advanced R-Matic Apparatus. The $k$ results at $75^{\circ} \mathrm{F}$ from the two testers agreed for material near the bag label density. Specimens of the cellulosic insulation were blown into these test frames and thermal tests are in progress. Blower-Cyclone-Shaker tests were completed on the cellulosic insulation to determine the settled density for conducting the thermal tests. All test materials for the 1990 Interiaboratory Comparison have been obtained.

We prepared and submitted to DOE/HQ draft one of a report entitled," 1990 Loose-Fill Insulation Interlaboratory Comparison Test Plan.". This report was due in July 1990 as an FY 1990 deliverable and reviews by ORNL staff have been completed to allow preparation of a final report. The report describes features of the thermal test apparatus, the components of a specimen preparation facility, a planned test schedule, and recommendations for use of this capacity in FY 1991 . 


\section{THERMAL INSULATION STUDIES}

D. W. Yarbrough, S. Wudhapitak, and M. Said Department of Chemical Engineering Tennessee Technological University Cookeville, Tennessee 38505

ORNL/SUb-7715/90

Air-flow permeabilities have been measured as a function of density for five insulations. Data were obtained for three fiberglass and two cellulosic products. The permeability of the cellulose insulations tested in the density range of application were a factor of ten less than the measured permeabilities for fiberglass in the density range of application. The data were obtained using a cylindrical specimen approximately six inches in diameter and eight to twelve inches long. Additional air-flow measurements with larger insulation specimens are planned.

3. STANCARD REFERENCE MATERIAL DEVELOPMENT

D. R. Smith

Chemical Engineering Science Division

National Institute of Standards and Technology

Boulder, Colorado 80303-3328

ORNL/IAA-21428/63

DOE/HQ has proposals from NIST under consideration. 


\title{
4. RESIDENTIAL INSULATION CORROSIVENESS
}

\author{
E. E. Stansbury \\ Consultant \\ 5800 Woodburri Drive \\ Knoxville, Tennessee 37919 \\ ORNL/SUb-B8240/27
}

Circulation of the direct reading corrosion rate meter (Corrater) to participants in the ASTM roind robin program to evaluate its use for assessing the corrosiveness of residential building thermal insulation is considerably behind schedule. The instrument, which was scheduled for shipment to seven participants, has just recently been passed to the fourth participant. To expedite the program, the instrument that has been used in the insulation corrosiveness program at the University of Tennessee has been shipped for circulation to two participants. The objective is to have results of the eight sets of measurements correlated for consideration by the ASTM 16.31 Corrosion Task Group at the meeting in October.

The information generated at the University of Tennessee on the corrosiveness of a range of cellulosic mineral fiber and foam insulations using several electrochemical methods is being placed in final draft report form.

\section{RESIDENTIAL INSULATION CORROSIVENESS}

\author{
E. E. Stansbury \\ Materials Science and Engineering Department \\ University of Tennessee. \\ Knoxville, Tennessee 37919 \\ Martin Marietta Energy Systems, Inc. \\ 99732PAX/11 \\ Consultant's Report
}

No progress to report for the month of July. 


\title{
6. RESEARCH AND DEVELOPMENT DATA TO DEFINE THE THERMAL PERFORMANCE OF REFLECTIVE MATERIALS USED TO CONSERVE ENERGY IN BUILDINGS
}

\author{
A. 0. Desjarlais \\ Thermatest Division of Holometrix, Inc. \\ Cambridge, Massachusetts 02139 \\ ORNL/SUb-SA835/23
}

\begin{abstract}
We received a request from the Reflective Insulation Manufacturers Association (RIMA) to borrow the mattes for the Reflective Insulation handbook contained in ORNL/Sub/88-SA835/1. RIMA would like to print and distribute copies of the Handbook. We are seeking DOE/HQ approval for this.
\end{abstract}

\section{RADIATION CONTROL. COATINGS}

Robert. W. Anderson

Robert W. Anderson and Associates, Inc.

Boulder City, Nevada 89005

ORNL/SUb-SE791/4

The planned exposure panel ( $4 \mathrm{ft}$ by $8 \mathrm{ft}$ ) with a radiation control coating on half of the panel was installed in the Roof Thermal Research Apparatus in July 1990. Two weeks of data from this system have been collected and are being analyzed. 


\section{TaSk B3. BUILDING MATERIALS PROGRAM MANAGEMENT SUPPORT}

\section{SUPPORT ACTIVITY - ORNL}

This task is focused on two topics:

(1.1) Exchange of technical results with the building materials community.

(1.2) Coordination of subcontracted research at other facilities.

1.1 Exchange - ORNL

R. S. Graves is Co-Chairman of the ASTM C 16 Second Symposium on Insulation Materials and has obtained over 40 abstracts from the Cail for Papers and direct contacts with Session Chairmen. These are being organized into a final program and acceptance letters to the authors will be issued by September 1, 1990. Manuscripts are due January 1, 1990, to allow the sympostum proceedings to be available by October 10, 1991 .

A one-hour workshop on innovative energy conservation trends was arranged for the Insulation Contractors Association of America meeting in Orlando. Talks will be given on CFC research (R. S. Graves), and evacuated panels (T. G. Kollie).

\subsection{Coordination - ORNL}

We are continuing to try to place a subcontract on research on advanced foams. We provided DOE/HQ with draft one of the Building Materials Research Project Fact Sheets for FY 1990 for their review. The report is a collection of nine project fact sheets to provide general information and narrative information. The Building Material Research Program activities are divided into thiree areas: Advanced Materials Research (3 projects), and Technical Support in Management and Administration ( 3 projects). A report entitled, "Moisture in Building Materials," by E. L. Bales, NJIT, was received and is being reviewed. 


\section{BUILDING ENVELOPE SYSTEMS}

ORNL. Staff:

J. E. Christian, K. E. Wilkes, R. L. Wendt,

G. E. Courville, P. W. Childs, and K. W. Childs

This task includes work done at ORNL and work by others on DOE-funded projects on Building Envelope Systems and is divided into Wall

Performance, Advanced Wall Systems, Foundation Systems, Roof Systems, and Building Diagnostics. Each of these project areas is treated separately on the following pages. 


\section{WALL PERFORMANCE}

1. THERMAL MASS SIMPLIFIED DESIGN TOOL ASSESSMENT

J. E. Christian

Oak Ridge National Laboratory

Oak Ridge, Tennessee 37831-6070

No progress to report for the month of July. 


\title{
2. DYNAMIC EVALUATION OF THERMAL BRIDGES
}

\author{
D. Burch \\ National Institute of Standards and Technology \\ Gaithersburg, MD
}

ORNL/IA-21513/23

\begin{abstract}
In this study, a finite-difference model is used to predict the steadystate and dynamic (time-dependent) performance of thermal bridges in a typical office butlding. The thermal bridges included in the analysis are a BUR roof with celling fasteners, a roof/wall interface, an insulated masonry cavity wall with steel studs, a slab floor penetrating an insulated masonry cavity wa11, and a window frame/wall interface. The goal of this project is to analyze the effect of these thermal bridges on the predicted space heating and cooling loads of the typical office building.

Progress Report for June 1990:
\end{abstract}

Milestone 2 (Complete TARP Simulations of Commercial Building): An attempt was made to incorporate the numerical coefficients into a bullding loads computer program called the Thermal Analys is Research Program (TARP). This effort was unsuccessful.

TARP predicts the heat-transifer response at butlding surfaces using transfer function equations that use surface temperature instead of air temperatures as driving force temperatures. This means that the conduction transfer function (CTF) coefficients used in TARP must not include the air film resistances. Yet, in the numerical approach used to determine the CTF coefficients, it was essential that reasonable air film resistances be included at both the interior and exterior surfaces. otherwise, constant surface temperature is inappropriately imposed at the boundary conditions. After the numerical CTF coeffictents were determined, the authors were unable to find a way to remove the effect of the air film resistance from the numerical CTF coefficients. 


\title{
3. VALIDATION OF MOISTURE-TRANSFER MODEL
}

\author{
D. Burch \\ National Institute of Standards and Technology \\ Gaithersburg, Maryland 20899
}

ORNL/IA-21513/23

\section{Progress Report for June 1990:}

Milestone 3 (Complete Final Report on Sensitivity Analys ts): The final report on the moisture sensitivity analysis is undergoing the editortil review process at NIST.

The report describes the NIST Molsture Transfer Model that predicts the combined transfer of heat and moisture through mult-1ayer butlding construction under non-steady-state conditions. The model includes the effect of vapor diffusion transfer, caplllary transfer, and convection transfer (i.e., infiltration and exflitration). The model can simulate the moisture performance of a wide range of building constructions and uses WYEC weather data as input.

In the report, the model is subsequently used to predict the avarage moisture content in the sheathing and siding of wood-frame cavity wall as a function of time of year. In the analysis, hourly WYEC weather data are used for a mild winter climate (Atianta, GA), an intermediate winter climate (Boston, MA), and a cold winter climate (Madison, WI) For the analysis, the indoor temperature is maintained at $70^{\circ} \mathrm{F}$, and separate computer runs are carrled out for indoor relative humidities of $35 \%$ and $50 \%$.

The effect of several construction parameters on the winter moisture accumulation are investigated. The parameters include the interior vapor retarder permeance, sheathing permeance, exterfor paint permeance, indoor air leakage, and the amount of cavity insulation. In addition, a controversial moisture management technique, outdoor ventilation of a cavity between the sheathing and siding, is investigated.

The traditional moisture management techniques of providing a vapor retarder and sealing interior air leakage paths were found to be effective in controlling winter moisture accumulation. However, the technique of outdoor ventilation of a cavity between the sheathing and siding was found to be tneffective.

ORNL funding has just been received and work is just commencing for FY 1990 project work. 


\title{
ADVANCED WALL SYSTEMS
}

\section{MOISTURE CONTROL HANDBOOK \\ Joseph Lstiburek \\ Dames Moore, Trow \\ Park Ridge, Illinots 60068 \\ ORNL/SUb-SD350/6}

\begin{abstract}
A Pagemaker version of the draft Motsture Control Handbook was distributed to the Review Panel on August 2, 1990. The detalls are presented in the same style as used in the Buflders Foundation Handbook. The feedback from the committee has led to a change in format which will reduce some text redundancy. It was recognized that there will be two types of readers; the one that uses only parts of the handbook, and one that reads through the entire document. It was also recognized that the text needs to be presented in such a manner so as to indicate what is repeated and what is new material. Several new sections will be added to the next draft: wetting and drying rates, HVAC pressurization techniques, and a section on attic and crawl space ventilation. The handbook suggests that the indoor relative humidity in the interior conditioned space be kept at $35 \%$ in the heating season. This received lengthy discussion which led to an agreement to change this to conditions based on dew point and a function of outdoor conditions. The comments from the August 2, 1990, review and the additional sections will be contained in a next draft to be distributed on September 3 , 1990.
\end{abstract}




\section{FOUNDATION SYSTEMS}

\section{BUILDING FOUNDATIONS RESEARCH AGENDA}

J. E. Christian

Oak Ridge National Laboratory

Oak Ridge, Tennessee 37831-6070

The ESRA construction continues to make good progress. The dry wal1 installation is complete, the doors are on, and the final touches are being installed inside. The power line above the building has been relocated and the building is ready for electric hook-up. A quotation has been requested to conduct the construction portion of the basement insulation installation and backfilling of the north basement wall.

The subslab access holes were used to conduct a preliminary survey of the presence of radon. Several holes contained 100 to 125 pico curies per ifter. The majority contained only background readings. This will be rechecked once the side walls are backfilled.

2. SLAB FOUNDATION BENCHMARK MODEL

D. Wasserman and Jeff Christian Oak Ridge National Laboratory Oak Ridge, Tennessee 37831-6070

No significant progress to report this month. 


\section{FOUNDATION THERMAL PERFORMANCE SIMPLIFIED PREDICTION TOOL Jeff Christian \\ Oak Ridge National Laboratory Oak Ridge, Tennessee 378.31-6070}

The Builders Foundation Handbook received its final DOE review on August 2, 1990. Some good comments were received from Ned Nisson, Energy Design Update; Steve Bliss, Journal of Light Construction; and Ken Labs, Progressive Architecture. The optimum insulation tables for 5 typical climates based on 30 year life-cycle cost analys is at a medium energy price have been removed from the main body of the handbook and put in the appendix. They will be used as examples of the type of information the user can produce with the worksheets that are contained in the Appendix. A final draft will be prepared which will include the accepted comments presented at this review and approval for publication requested from DOE. 
ROOF SYSTEMS

\title{
1. ROOFING RESEARCH CENTER
}

\author{
R. L. Wendt \\ Oak Ridge National Laboratory \\ Oak Ridge, Tennessee 37831-6070
}

\begin{abstract}
Activities at the Center included the completion of the initial series of tests with the Attic Test Module (Item 6) to investigate convective heat loss through ? ow-density, loose-fill fibrous glass insulation and the evaluation of various means to mitigate this phenomena. Work continued on the Roof Mechanical Properties and Foundation Research Apparatus (Item 8). A test panel to evaluate radiation control coatings was installed on the Roof Thermal Research Apparatus (RTRA) in early July. This panel consists of a $1 \frac{1}{2}$ in. uninsulated plywood deck covered with a black EPDM membrane. Half of the panel was coated with a commercisi reflective coating with a thickness of 30 mils, the rest remained uncoated.
\end{abstract}

\section{LARGE SCALE CLIMATE SIMULATOR}

\section{P. W. Childs, K. E. Wilkes, and T. W. Petrie Oak Ridge National Laboratory Oak Ridge, Tennessee 37831-6070}

Runs continued with the attic test specimen, using the LSCS as a guarded hot and cold box. Various Attic Seal products were installed over the 10 inches (nominally R-21) of loose-fill fiberglass insulation. Both winter and summer runs were completed with the products. Infrared thermography was also done on the membrane as the attic air temperature rose from about $-5^{\circ} \mathrm{F}$ to $45^{\circ} \mathrm{F}$.

The results of this testing were provided to the sponsor for evaluation and guidance as to future directions. This phase of the testing is complete.

The new pneumatic control for the metering chamber water flow loop has arrived. It was decided to delay installation of the valve until the current testing is completed. The calibration sample will be inserted in the chamber and some of the tests that were run on the Attic Seal product will be duplicated. 


\section{IEA ANNEX 19 ON LOW SLOPE ROOF SYSTEMS}

George E. Courville

Oak Ridge National Laboratory

Oak Ridge, Tennessee 37831-6070

Annex 19 on the Buildings and Community Systems Working Group of the International Energy Agency met in June. This Annex is preparing a document on good practices for the design, installation, and maintenance of low slope roofing. A first draft of this document was reviewed and assignments were made to improve most sections. The next draft will probably be circulated to roofing professionals in other countries to improve the data base and the design perspectives.

\section{ATTIC TESTING IN THE LSCS \\ Kenneth E. Wilkes and Agnes Delmas \\ Oak Ridge National Laboratory \\ 0ak Ridge, Tennessee 37831-6070}

Testing of 10w-density loose-fill fiberglass insulation in the Attic Test Module continued during July. Series of tests have been completed with the loose-fill insulation only, and with the insulation covered with several types of materials. Data from these tests continue to be analyzed.

A draft of a technical paper on attic testing in the LSCS has been written for the International Symposium on Roofing Technology to bc held in April 1991. The paper gives data from the attic tests with no insulation and with low-density, loose-fill fiberglass insulation with no covering material. 


\title{
5. FIELD TESTING OF ISOCYANURATE FOAMS WITH ALTERNATE BLOWING AGENTS
}

\author{
J. E. Christian and G. E. Courville \\ Oak Ridge National Laboratory \\ 0ak Ridge, Tennessee 37831-6070
}

As expected, the hot summer days have raised the mean insulation temperature of the foam specimens on the RTRA above $80^{\circ} \mathrm{F}$, and this has appeared to accelerate the aging. However, the six different systems continue to track each other in the same order as reported earlier.

During installation of BUR in the Envelope Systems Research Apparatus, thermocouples and heat flux transducers were hooked up to the data acquisition system. This data has been plotted and sent to NRCA, which shows the asphalt cooling rates. This data showed a maximum surface temperature of $274^{\circ} \mathrm{F}$. This may be of value to better understand the potential off-gassing of HCFC-133 (a potential carcinogen) from HCFC-123 blown boards. There were differences in the degree of blistering of the facers as the hot asphalt was applied and varying degrees of warping between the different boards. For the most part, there appeared to be no problems with the compressive strength of any of the alternative boards tested. The roof has been examined several times in July and several good sized blisters have been identified. Also, several fish mouths were discovered, two of which contained water under the top membrane layer. These have been reported to NRCA. Tom Smith, NRCA, suggested the two fish mouths should be patched with plastic cement by ORNL. The blisters will be watched closely for growth but for now left alone.

The paper for the 33rd Annual Polyurethane Conference on the analys is of the RTRA data has been edited by SPI, reviewed by the ORNL authors, and sent back for final placement on galleys.

A paper was submitted for the Third International Symposium on Roofing Technology, to be held in Montreal, Canada on Apri1 17-19, 1991. The title is, "Thermal Properties of Polyisocyanurate Foam Board Insulation Blown with CFC-11 Substitutes." This paper combines both the laboratory and field testing results to date on the polyisocyanurate HCFC test specimeris. 


\title{
6. ROOF MECHANICAL PROPERTIES RESEARCH APPARATUS
}

\author{
Robert L. Wendt \\ Oak Ridge National Laboratory \\ Oak Ridge, Tennessee 37831-6070
}

\begin{abstract}
The roof containing the five different polyisocyanurate insulation formulations was installed on June $26 \& 27$. Since then, it has been periodically inspected (both upner surface and under the deck). No leaking has been observed despite several significant storms since instaliation. The appearance of the roof during this period suggested that nothing unusual was happening. Samples of the installed roof were sent to the National Roofing Contractors Association for further tests and evaluation. Other work on the project focused on relocation of a high voltage power line which crosses the facility and the installation of electric power to the structure. Work remaining to be accomplished includes site grading, equipment start-up and check-out, and the installation of the initial series of foundation experiments.
\end{abstract}

\section{ROOFING INDUSTRY COMMITTEE ON WIND ISSUES}

\author{
George E. Courville \\ Oak Ridge National Laboratory \\ Oak Ridge, Tennessee 37830-6070
}

The Roofing Industry Committee on Wind Issues (RICOWI) held its first formal meeting in late Spring. A Nominations Committee has been charged to prepare a slate of officers which will be voted on at the next meeting. RICOWI has representation from all the major industry associations that service the roofing business. The primary objectives of RICOWI are to monitor and coordinate activities among laboratories doing research on roof wind uplift issues. In addition, RICOWI will review research needs, establish a consensus among members on priorities, and assist the industry in obtaining support for research on high priority issues. 


\section{BUILDING DIAGNOSTICS}

1. SOLAR REFLECTANCE MEASUREMENTS IN THE FIELD

George E. Courville Oak Ridge National Laboratory

Oak Ridge, Tennessee 37831-6070

No progress to report for the month of July. 


\title{
D. COOPERATIVE PROJECTS
}

\section{COOPERATIVE INDUSTRY/GOVERNMENT RESEARCH PROJECT ON AL.TERNATIVE BLOWING AGENTS}

\author{
G. E. Courville, D. L. McElroy, J. E. Christian, and R. L. Wendt \\ Oak Ridge National Laboratory \\ Oak Ridge, Tennessee 37831
}

This project is jointiy supported by the Department of Energy, the Environmental Protection Agency, The Soctety of the Plastics Industry, the Polyisocyanurate Insulation Manufacturers Association, and the National Roofing Contractors Association. The objective of the project is to conduct comparative laboratory and field studies of isocyanurate foam roofing boards blown with conventional CFC-11 and with al ternative blowing agents. The purpose is to identify performance differences, if any, between foams with alternative blowing agents and foam blown with CFC-11.

\section{MEETINGS AND PRESENTATIONS}

None.

\section{LABORATORY TESTING}

The testing of thin-specimens provided thermal conductivity ( $k$ ) data on specimens aged for up to 290 days at $75^{\circ} \mathrm{F}$ and 190 days at $150^{\circ} \mathrm{F}$. New fits by a least squares method were made for the correlation with (diffusion coefficient $x$ time) ) $^{1 / 2}$ thickness to yield effective diffusion coefficients for air components into the foam and blowing agent out of the foam. These were used to obtain activation energies $(\Delta H)$ for these processes. The $\Delta H$ (air) values for the five foams had an average value of $7300 \mathrm{cal} / \mathrm{mole}$ and the $\Delta H$ (blowing agent) values differed for each foam but were in the range 3600 to $6800 \mathrm{cal} / \mathrm{mole}$. We obtained the MIT computer program for aging and are running cases for comparison to the thin specimen testing results. An alternative analysis that is similar to the Dow diffusion model was suggested ana we plan to explore this model. The interlaboratory comparison of $k$ measurements at $75^{\circ} \mathrm{F}$ on two planed boards foamed with CFC-11 (age about 400 days) using 24 in. $x$ 24 in. R-Matic apparatuses was completed in July. We are preparing a letter report for review by the participants. We completed a set of transient tests on these boards prior to initiating this comparison (see Section B2).

\section{FIELD TESTING}

As expected, the hot summer days have raised the mean insulation lemperature of the foam specimens on the RTRA above $80^{\circ} \mathrm{F}$, and this has appeared to accelerate the aging. However, the six different 
systems continue to track each other in the same order as reported earlier.

During installation of BUR in the Envelope Systems Research Apparatus, thermocouples and heat flux transducers were hooked up to the data acquisition system. This data has been plotted and sent to NRCA, which shows the asphalt cooling rates. This data showed a maximum surface temperature of $274^{\circ} \mathrm{F}$. This may be of value to better understand the potential off-gassing of HCFC-133 (a potential carcinogen) from HCFC-123 blown boards. There were differences in the degree of blistering of the facers as the hot asphalt was applied and varying degrees of warping between the different boards. For the most part, there appeared to be no problems with the compressive strength of any of the alternative boards tested. The roof has been examined several times in July and several good sized blisters have been identified. Also, several fish mouths were discovered, two of which contained water under the top membrare layer. These have been reported to NRCA. Tom Smith, NRCA, suggested the two fish mouths should be patched with plastic cement by ORNL. The blisters will be watched closely for growth but for now left alone.

\section{ROOF MECHANICAL PROPERTIES RESEARCH APPARATUS}

The roof containing the five different polyisocyanurate insulation formulations was installed on June $26 \& 27$. Since then, it has been periodically inspected (both upper surface and under the deck). No leaking has been observed despite several significant storms since installation. The appearance of the roof during this period suggested that nothing unusual was happening. Samples of the installed roof were sent to the National Roofing Contractors Association for further tests and evaluation. Other work on the project focused on relocation of a high voltage power line which crosses the facility and the installation of electric power to the structure. Work remaining to be accomplished includes site grading, equipment start-up and check-out, and the installation of the initial series of foundation experiments. 

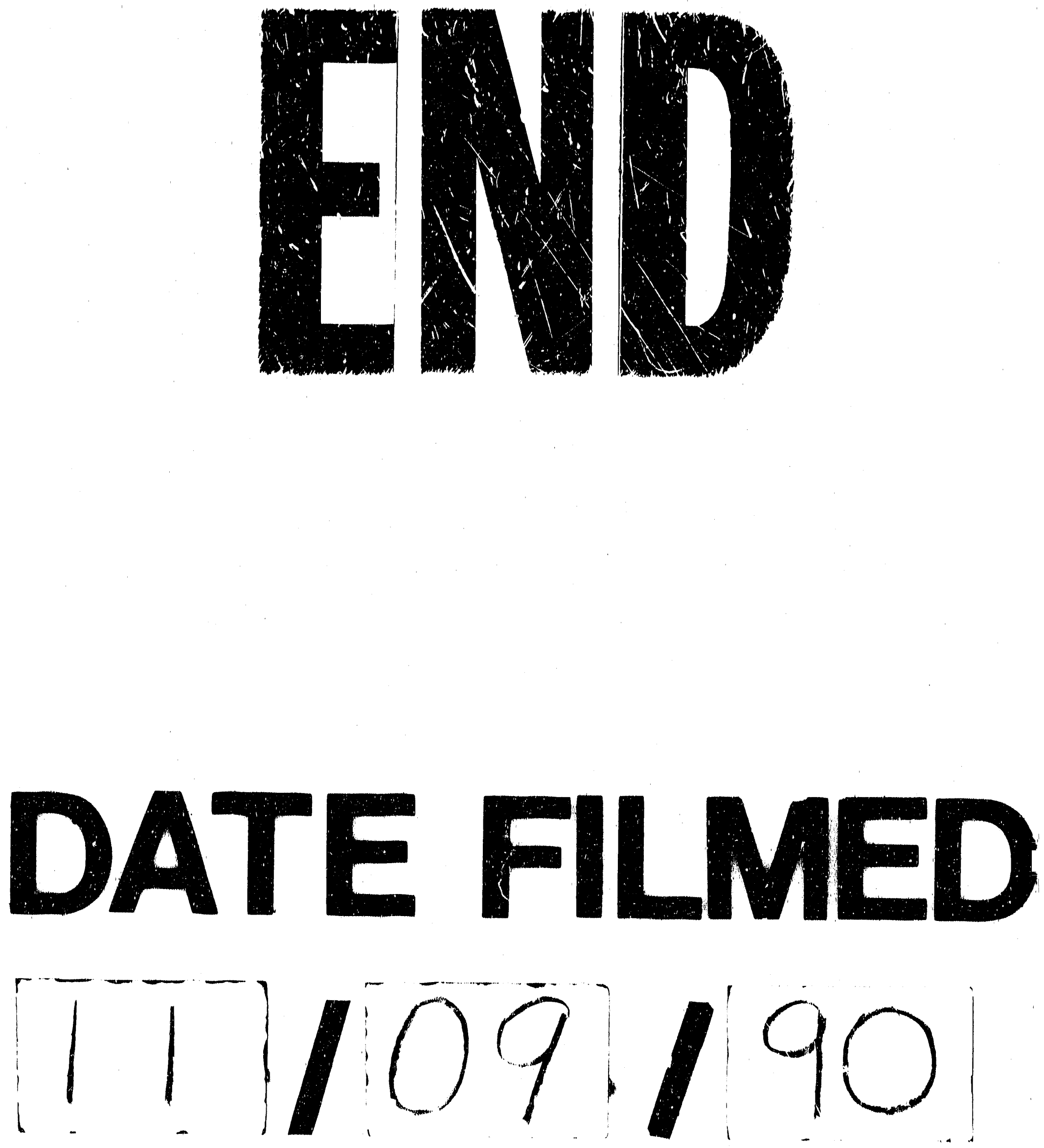
